\title{
The Effect of "Camp to Add" on Port Enterprises and the Countermeasures
}

\author{
Shan Wang \\ School of Business Administration South China University of \\ Technology , Guangzhou 510640, China \\ 750385345@qq.com
}

\section{Keywords: The camp Port Enterprises Influence}

\begin{abstract}
At present, our country "camp to add" tax reform, this reform to promote the adjustment of our economic structure and industrial upgrading, also had a profound impact on China's economy. Among them, logistics support services have also been incorporated into the scope of the pilot reform, become the focus of the reform. In this paper, through the analysis of calculating trial "camp to add" policy on the Hong Kong Group, the effect of "camp to add" brought to the port enterprises, and puts forward some suggestions on further reform, promote the sustainable development of enterprises, guarantee the tax system reform.
\end{abstract}

\section{Introduction}

Since 1994 when China implemented the value added tax and business tax system are levied on goods and services, play an important role in promoting the development of socialist market economy. But along with the social division of labor is increasingly refined, the burden of VAT taxpayer outsourcing services this tax structure of the business tax, the tax burden of taxpayers purchasing goods business value-added tax, are not deductible, double taxation problem has not completely eliminated, not conducive to the adjustment of economic structure and the modern service industry development. The business tax levy value-added tax, the scope of vat cover all goods and services, not only in line with the common practice of the world, is the inevitable choice to improve the scientific development of the tax system. Therefore, "camp to add" is an important step for the country to structural tax reduction.

2011, approved by the State Council, the VAT pilot program to send business tax change the Ministry of finance, the State Administration of Taxation jointly. From January 1, 2012 onwards, carry out pilot VAT reforms in Shanghai transportation industry and part of modern service industry.

\section{Main content of "camp to add" tax reform}

\subsection{The range of "camp to add "tax reform}

According to the "notice" the Ministry of Finance and the State Administration of Taxation on the transportation industry and part of modern service industry in Shanghai city pilot VAT reforms to the provisions of article eighth, the "camp to add" pilot industry into two industries.

(1) The transportation industry, including: land transport services (railway transportation except), water transport services, air transport services, pipeline transportation services.

(2) Part of the modern service industry, including: research and development and technical services, information technology services, cultural and creative services (design services, advertising services, convention and exhibition services), logistics support service, tangible movable property leasing services, verification consulting services and radio and television services; 3 postal service industry. 
But not including the construction industry, communication industry, the financial insurance industry and service industry etc.

\section{2 "Camp to add" tax reform of the tax system}

\section{(1) Taxpayer}

Divided into value-added tax general taxpayer and small-scale taxpayers. Among them, for 12 consecutive months providing taxable services sales of more than 5000000 yuan, is a general taxpayer; units and individuals without more than for the small scale taxpayer. But the original highway, inland freight invoice issuing taxpayers, with annual sales of not more than 5000000 yuan shall be identified as the general taxpayer.

\section{(2) Tax rate}

The general taxpayer in current standard VAT rate of $17 \%$ and $13 \%$ low tax basis, add $11 \%$ and $6 \%$ two low tax rates. Among them. Leasing of tangible movable property and other applicable tax rate $17 \%, 11 \%$ tax rate applicable to the transportation sector, $6 \%$ tax rate applicable to modern service industry. Small scale taxpayers providing taxable services, the tax rate to $3 \%$.

\section{(3) Tax mode}

The transportation industry, construction industry, post and telecommunications industry, modern service industry, the sports industry style, the sale of real property and the transfer of intangible assets, in principle applicable to general VAT tax method. Finance and insurance industry and service industry, in principle applicable value added tax simple tax method.

\section{3 "Transitional policy to increase the camp" reform of the tax system arrangement}

\section{(1) Tax revenue ownership}

During the pilot period income remain unchanged, the original ownership pilot areas of the business tax income, change after VAT still belongs to all the pilot area, VAT, income tax surcharge fines are vested in the pilot areas. VAT revenue is not included in the pilot area of central on the value-added tax and consumption tax return of base. Because the pilot VAT reforms happened financial income changes, pilot areas by the central government and in accordance with the relevant provisions of the existing financial system share.

\section{(2) Transitional financial support}

During the pilot, the pilot enterprise business tax change after VAT to pay value-added tax according to the original business tax actually increased, will enjoy the transitional financial support policy; according to the current financial system regulations and does not increase the enterprise tax burden principle, set up "pilot VAT reforms to financial support fund", for the special value-added tax business tax on the financial support of funds to support pilot enterprises; take "monthly, quarterly, annual advance liquidation" way, increase enterprise of tax exemption and reduction of preferential support; part of the business tax policy adjustment, to be refunded. 
"Camp to add" in the pilot stage, the overall tax burden of port enterprises has increased, after analysis, the following reasons resulting in "camp to add" port enterprise's tax burden does not fall to rise instead.

\subsection{Differences in business tax and value added tax characteristics}

Business tax is the tax within the price, in the income tax expenses, so as to offset part of the tax, so the actual tax burden level is lower than the actual tax rate level.

The value-added tax is not the money, in the income tax expenses, nor can deduct the income tax, so the actual value-added tax burden level not lower than the actual value added tax rate. The actual value-added tax burden level will depend on the value-added tax rate and tax deductible proportion and input offset the cost for turnover. If the deductible items less, causes the deductible costs in the turnover in the proportion of low or input touch buckle tax rates low, it may lead to even in the value added tax and business tax rates the same, the actual value-added tax burden is still higher than the actual tax burden. If the actual value-added tax rate is higher than the tax rate, meanwhile there are deductible in the cost of sales in the proportion of low or input deduction rate low, will cause the actual value-added tax burden is higher than the tax burden.

\subsection{The current implementation of the port business price include tax}

Charge current of port enterprise business price is formulated and promulgated by the state, the port enterprise fees are executed according to the rules established port charges. Port operations include price before tax, in the "camp to add", for the tax price. In the implementation of the "camp to add" pilot scheme, the value-added tax is essential in port business, prices remain unchanged, the port enterprise transactions according to this price, and ultimately will cause the enterprise tax burden, lower income.

\subsection{The deductible items less lead to tax increases}

\section{(1) Labor costs are not deductible}

Port enterprises are labor-intensive enterprises, labor costs accounted for more than $35 \%$ of the total cost of the operating costs, accounted for a high proportion of. But according to the Provisional Regulations on value added tax, cost of the part cannot be offset in the input tax. While allowing deduction of fuel, power, materials and equipment repair and other projects accounted for a very small proportion of operating costs, which led to the increase of port enterprise tax burden, restricting the level of corporate profits increased. Compared to the cost of material is deductible, companies tend to reduce labor costs in the proportion of operating costs, and increase profitability.

Investment property is not deductible

Port enterprises are capital intensive enterprises, the initial one-time investment amount. In the "camp to add" before, the port enterprises have invested a larger proportion of the immovable property investment, and in accordance with the provisions of the Provisional Regulations on value added tax, the proportion of investment in port enterprises greater investment property is not in the VAT tax range. According to the characteristics of port industry, when the enterprise enters the mature period of relatively stable, the annual increase of equipment and other real estate investment will be less, the input tax also produces less. The value-added tax is in accordance with the VAT 
input tax reduction after the balance is paid, the non deductible range is bound to cause the port enterprises, the input tax deduction, caused the increase of port enterprise tax burden.

\subsection{Value added tax special invoice to receive non-standard}

In the implementation of "camp to add", the value-added tax policy requires the enterprise to be able to accurately calculate the output tax and VAT deduction vouchers, and made in accordance with the provisions to offset. But due to the nature of the service industry, the actual business of port enterprises, on behalf of the more common situation. Usually, the port enterprises in the Commission in accordance with the actual settlement price issue VAT invoices, but in the implementation of business but because the cause of the settlement is very difficult from the third party immediately receive all of the value-added tax invoices, two aspects of the settlement time difference. The value-added tax is tax payment according to the invoice, and by deduction. This leads to the port enterprises have to pay a tax is not actually should take in the current period, enterprises are usually regarded as deferred income, but this part of it will affect the daily turnover of capital; at the same time, due to the port business complex, in the choice of oil products, maintenance and machinery suppliers, easy to ignore the qualification whether has the VAT invoice, so as to make the enterprise tax loss; again, in many small business, in order to simplify the work of ordinary invoice, mostly on the amount of small, high frequency operation, the input tax cannot be deducted, increase the value-added tax to pay taxes.

\subsection{Increased costs lead to decreased level of profitability}

Tax costs, it is difficult to improve the level of profitability

Port enterprises are labor-intensive enterprises, the human cost is difficult to reduce, and not deductible. Therefore, the goal of improving the operational efficiency of port enterprise is more in order to save material consumption. And in "camp to add" mode, reduce material consumption, decreased the deductible items, the input tax decrease, should pay value-added tax increases. Therefore, reduces the enterprise to improve the operational efficiency of enthusiasm.

(2) Increase the tax burden is difficult to pass on

China port enterprises competition, port enterprises is not high to the shipper and the shipping company bargaining power, cause an increase in the tax burden to raise the price to the way to the customer transfer. And China's value-added tax is not a comprehensive value-added tax, only in some provinces and municipalities and industries, thus caused the discrepancy between the value-added tax collection of links, resulting in port enterprises difficult to pass out of the increased tax burden.

\section{$4 \quad$ Planning and the proposed tax}

\subsection{Expand the scope of value-added tax reform, to seek more policy support}

(1) Speed up the "camp to add" by part area, part of the industry spread to other regions and other industry, comprehensive value-added tax as soon as possible, to cover all the service industry, which makes the industry VAT deduction chain tends to be complete, reducing the pressure of the pilot area of business tax.

(2) Port enterprise is the basis of national industry, the port development of high-tech industry and port industry, attract foreign capital more and advanced technology, the development of its resources. The port can escalate into a trade business and financial function development of opening to the outside world, is the world trend of port development. All countries in the world have more 
preferential tax policies on the. The government can adopt more preferential policies of the bonded port area, such as Shanghai Yangshan Port in loading and unloading terminals business VAT Jizhengjitui etc.. To promote the development of port enterprise.

(3) In the "camp to add" at the beginning, the business tax rate as the benchmark rate that port enterprises super tax return, enterprises in the actual operating process of tax burden below according to the benchmark rate, pay taxes according to the actual tax; enterprise in the actual operating process of high taxation in according to the benchmark rate, the excess tax will be refunded. That can keep the port enterprise sustained development, and steadily push forward the help of tax reform, tax burden balance of port enterprises.

\subsection{To expand the scope of offset}

(1) Different from other enterprises, the port industry demands high infrastructure construction, huge investment and long service time. And for the entering the mature stage of the port enterprises, annual investment in fixed assets such as machinery and equipment relatively less. Immovable property investment belongs to non VAT taxable items, the tax can not be deductible input tax, resulting in smaller. Therefore, suggestions of immovable property take transitional credit policy in the reform period, so as to expand the input tax deduction scope, reduce the port enterprise tax burden.

(2) Port enterprises are labor-intensive enterprises, labor costs accounted for a larger proportion of operating costs, because this part is not in the scope of "camp to add" value-added tax deductible, so enterprises increase the tax burden. According to the artificial cost of port enterprises large enterprises such as artificial cost deduction, or according to a certain proportion of deduction, value-added tax to reduce the tax burden of port enterprises.

\subsection{Changes in value added tax}

"Camp to add", the port enterprise tax rate increase. For example, port enterprises terminal services, the original business tax rate is $3 \%$, in the "camp to add", the value-added tax rate of $6 \%$, the tax rate increase 1 times. The existing value-added tax rate of port enterprises is significantly higher, the tax burden on port enterprises increase. However, the tax policy should maintain a certain stability, frequent changes in tax rates will cause adverse effects. At present, belonging to the transition period, suggestion again during the tax subsidies and preferential to port enterprises, to achieve a smooth transition. After the full implementation of value-added tax, can consider to adjust the port enterprise value-added tax according to the actual situation of the port enterprise tax burden.

\section{Conclusion}

At present, China's "camp to add" still not covering all the range, all of the industry, with the passage of time, the comprehensive Chinese value-added tax will be taken and the most developed countries in the world of VAT Type convergence. China should speed up the "camp to add" process ", to further improve the content and significance of the camp", to promote the development of our economy

\section{References}

1. Tao Minghan. Influence of business tax on the value added tax of port enterprises. Economic Research Guide.2013.21.

2. Chen Jun. Influence of business tax VAT on port enterprise financial sector.2013.1. 
3. Chen Yanshan, Qu Yang. Influence of business tax VAT on port enterprise. Traffic accounting.2012.10.

4. Sun Dehong. "Camp to add" make the port enterprise tax burden "no reason and remedial measures to rise". China port.2012.7.

5. Zhang Zhuojie, Song Liangrong. "Camp to add" tax effect on port enterprise financial and economic.2013.14. 